\title{
New species of the pericaline genus Tantillus (Coleoptera: Carabidae: Lebiini)
}

\section{Новые виды рода Tantillus (Coleoptera: Carabidae: Lebiini)}

\author{
D.N. Fedorenko \\ A.H. Федоренко
}

A.N. Severtsov Institute of ecology and evolution, Leninsky pr. 33, Moscow 119071, Russia. E-mail: dmitri-fedorenko@yandex.ru. Институт проблем экологии и эволюции им. А.Н. Северцова, Российская Академия Наук, Ленинский пр-т, 33, Москва 119071, Россия.

KEY WORDS: Coleoptera, Carabidae, Tantillus, Mochtheroides, new species, new synonym, Vietnam, Oriental region.

КЛЮЧЕВЫЕ СЛОВА: Coleoptera, Carabidae, Tantillus, Mochtheroides, новый вид, новый синоним, Вьетнам, Ориентальная область.

ABSTRACT. The little-known ground beetle genus Tantillus Chaudoir, 1869 = Mochtheroides Andrewes, 1923, syn.n., is redescribed. Six new species, T. quadripunctatus sp.n. from Sri Lanka, T. reflexicollis sp.n. from southern India, T. imbricatus sp.n. from Borneo, $T$. subnitens sp.n., $T$. longipenis sp.n., and $T$. semiopacus sp.n., all from southern Vietnam, are described. Key to the species is provided.

РЕЗЮМЕ. Переописан малоизвестный род Tantillus Chaudoir, $1869=$ Mochtheroides Andrewes, 1923, syn.n. Описано 6 новых видов: T. quadripunctatus sp.n. из Шри Ланки, T. reflexicollis sp.n. с юга Индии, T. imbricatus sp.n. с Борнео, а также T. subnitens sp.n., T. longipenis sp.n., и T. semiopacus sp.n. с юга Вьетнама. Составлена определительная таблица видов.

\section{Introduction}

Tantillus Chaudoir, 1869 and Mochtheroides Andrewes, 1923 are little-known oligotypic genera of the subtribe Pericalina, Lebiini. The former genus includes two species from Sri Lanka and the latter is known to be more widespread and includes three species, one described from Myanmar and the other two from the Philippines. According to the descriptions, the two genera are very similar. No exact data on habits and habitats of the species have hitherto been reported.

In this paper we describe six new species of Tantillus (= Mochtheroides, syn.n.). Three of them have been explored during field trips to some regions of Vietnam, sponsored by the Russia-Vietnam Tropical Centre, Moscow-Hanoi.

The acronyms used are as follows: MNHN, Muséum national d'Histoire naturelle, Paris; SIEE, the author's reference collection at A.N. Severtsov Institute of Ecol- ogy and Evolution, Russian Academy of Sciences, Moscow; ZISP, Zoological Institute, Russian Academy of Sciences, St. Petersburg; ZMMU, Zoological Museum of the Moscow State University.

The following parameters were analyzed: BL maximum body length measured between apices of closed mandibles and apices of elytra; D1 - distance between elytral base and seta d1; EL - maximum length of elytron, measured from highest point of base to apex; EW - maximum width of elytra; HW — width of head across eyes; PL - length of pronotum along median line; PW - maximum width of pronotum; $\mathrm{PWa}$ - width of pronotum between apical angles; $\mathrm{PWb}$ - width of pronotum between basal angles. Measurements were taken using an eyepiece micrometer, to two decimal places. The number of specimens measured (n) is only given for the first ratio in the description. Data on labels of type specimens are in quotes.

\section{Results}

Tantillus Chaudoir, 1869

Chaudoir, 1869: 126; Csiki, 1932: 1354. - Mochtheroides Andrewes, 1923: 50, syn.n., type-species: Masoreus sericans Schmidt-Göbel, 1846, by monotypy; Jedlička, 1963: 352; Csiki, 1932: 1383; Darlington, 1968: 123.

Type-species: Tantillus brunneus Chaudoir, 1869, by monotypy.

DIAGNOSIS. A member of the subtribe Pericalina, Lebiini, distinctive in the combination of the body small-sized, tarsal claws denticulate, two gular setae present (sometimes absent), femora incrassate, metafemur anteroventrally with a long preapical seta, pronotum convex, mostly with very narrow reflexed lateral margin, elytra flattened, parallelsided, and elytral chetotaxy peculiar.

REDESCRIPTION. With characters of the Pericalina. Body macropterous, small-sized and slightly flattened (Figs 1-7). Dorsum unicoloured black or dark brown, moderately shiny to dull from coarse microsculpture; mouthparts, anten-

How to cite this article: Fedorenko D.N. 2018. New species of the pericaline genus Tantillus (Coleoptera: Carabidae: Lebiini) // Russian Entomol. J. Vol.27. No.3. P.241-248. doi: 10.15298/rusentj.27.3.02 
nae and legs, including coxae and trochanters, red, femora more or less infuscated except at bases and at apices; abdomen often reddish. Integuments generally glabrous, dorsum with almost indistinct ciliae here and there, underside a bit more densely ciliate, more so at apical margin of abdominal sternite VII, rather sparsely setulose along middle of mesoand metaventrite; tarsi nearly glabrous or minutely and rather sparsely setulose, with few fairly long dorsal setae.

Eyes medium-sized, convex or slightly flattened, genae long, as long as or slightly shorter than eye, meeting neck at very obtuse angle, sometimes (type species) smoothly extended into neck; neck constriction conspicuous to indistinct. Frontal foveae absent or almost so. Clypeus transversely hexagonal, evenly concave at apical margin. Labrum sexsetose, transverse to longitudinal, with rounded angles. Antennae densely pubescent from middle of antennomere 4 onwards, filiform and moderately long, surpassing pronotal base by about apical two segments; antennomere 3 slightly shorter than scape, not more than two fifths longer than pedicel, as wide as or barely longer than antennomere 4; scape with long dorso-

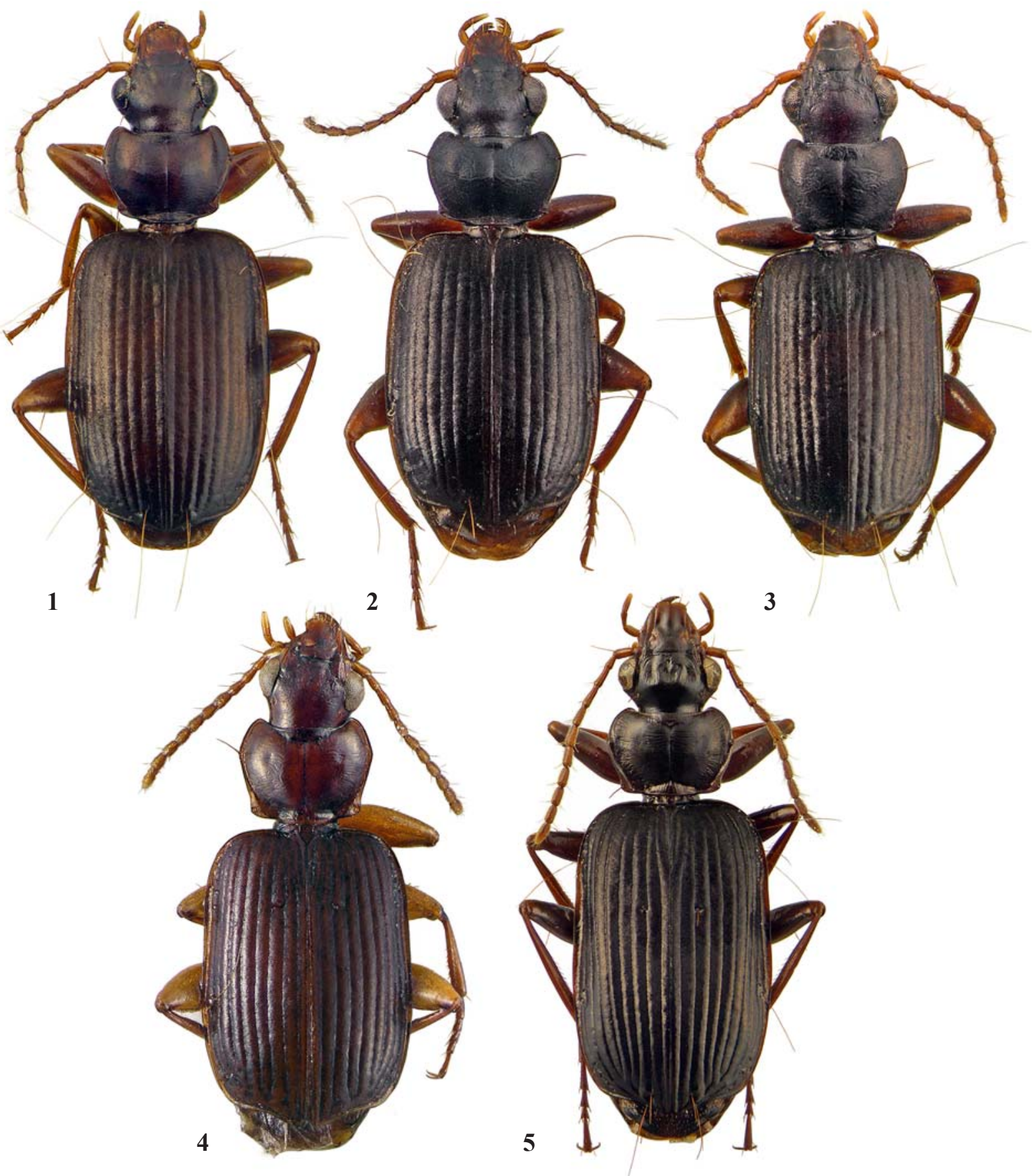

Figs 1-5. Dorsal habitus: 1 - Tantillus semiopacus sp.n., + paratype from Long Lanh; 2 - T. longipenis sp.n., holotype; 3 - T. quadripunctatus sp.n., holotype; $4-$ T. brunneus, lectotype; $5-T$. imbricatus sp.n., holotype.

Рис. 1-5. Габитус сверху: 1 - Tantillus semiopacus sp.n., ㅇ паратип из Лонг Лан; 2 - T. longipenis sp.n., голотип; 3 - T. quadripunctatus sp.n., голотип; $4-$ T. brunneus, лектотип; $5-$ T. imbricatus sp.n., голотип. 
apical seta and an additional ventro-apical seta; pedicel with three verticellate setae; antennomere 3 with verticellate setae and a few, mostly ventral, shorter additional setae between them. Gula bisetose, sometimes one or two setae reduced; one paragular seta on each side; submentum generally sexsetose, i.e., with one pair of long setae, two shorter setae between them and a similar seta close to lateral margin; mentum bisetose, with a short, apically rounded, median tooth; ligula moderately wide, slightly dilated apicad, truncate, with a few short ventral setae in addition to four long apical ones; paraglossae adnate to and much surpassing ligula in front. Maxillary stipes at outer margin with two setae, basal and apical. Penultimate labial palpomere with two setae across extreme apex of inner margin. Maxillary and labial palps with terminal palpomere fusiform, twice as long as penultimate palpomere on labials.

Pronotum cordate to inversely trapezoidal, bisetose on each side, convex or very so, with lateral margins mostly narrowly explanate and reflexed; base truncate or with median part slightly produced; apex sinuate, with porrect and fairly acute angles. Median line deep, apical and usually basal impression distinct, apical bead obliterate medially. Basal foveae imperceptible.

Elytra square, short and parallel-sided or nearly so; humeri and posterolateral angles rounded; apical truncature oblique, gently sinuate, apices blunt. Basal ridge entire, reaching scutellum or nearly so, with humeral angle indistinct or (sometimes) hardly traceable opposite or just outside stria 3; reflexed lateral margin narrow and smooth. Elytral striae mostly impressed but a little, impunctate or almost so. Parascutellar striole long; parascutellar setigerous pore just behind or touching basal ridge, not or barely adjoining stria 1 and sometimes also 2 . Interval 3 with 1-2 discal setae, d1 before middle and/or d3 adjoining stria 2 near apex. Stria 7 with two preapical setae, anterior long and situated close to $\mathrm{d} 3$, posterior short. Interval 9 with umbilical seta series consisting of $8+2+4$ umbilical setae arranged into three widely separated groups: subhumeral, con- sisting of eight close setae, with seta 6 adjoining stria 9; postmedian (two close setae); and subapical (four setae).

Underside: Metepisternum long. Abdominal sternites IVVI each with one pair of obligatory setae; sternite VII bisetose in both sexes, apical margin straight in female, more or less emarginate medially in male.

Legs: Claws denticulate. Femora mostly incrassate, often with a shallow, longitudinal, ventral groove in apical $1 / 4-1 / 2$ to receive tibiae; metafemur mostly bisetose, with distal seta strong and situated closer to apex, sometimes with four strong setae. Chetotaxy otherwise as follows: procoxa with one posterior seta (sometimes accompanied by 1-2 additional shorter setae); profemur posteriorly with basal, medioventral and vestigial preapical seta; metacoxa bisetose, with anterolateral and inner setae; trochanters with seta, tarsomere 5 with one pair of ventral setae.

Sexual dimorphism. Males are distinctive in having basal three protarsomeres dilated and biserially squamose ventrally; mesotibia with inner margin tuberculate towards apex; profemur and mesofemur in basal half with moderately long ventral pubescence. Abdominal sternites III and IV each sometimes with a median tuft of strong and fairly short setae, combined with glabrous pro- and mesofemora.

Aedeagus (Figs 8-37): median lobe well sclerotized throughout, slightly asymmetric, with apical orifice welldefined and slightly to distinctly shifted to the left side; apex short to very long. Internal sac with small or no spines. Female gonocoxite IX subtriangular, curved outwards and pointed apically, with strong ensiform setae, one dorsal (inner) and two ventral (outer).

DISTRIBUTION. The genus is widespread in the Oriental Region east to and including the Philippines and New Britain, extending westward as far as India and Sri Lanka. Most species are not very common nevertheless. The oldest described species, T. sericans, has been reported from Burma, Singapore and Sumatra [Andrewes, 1933].
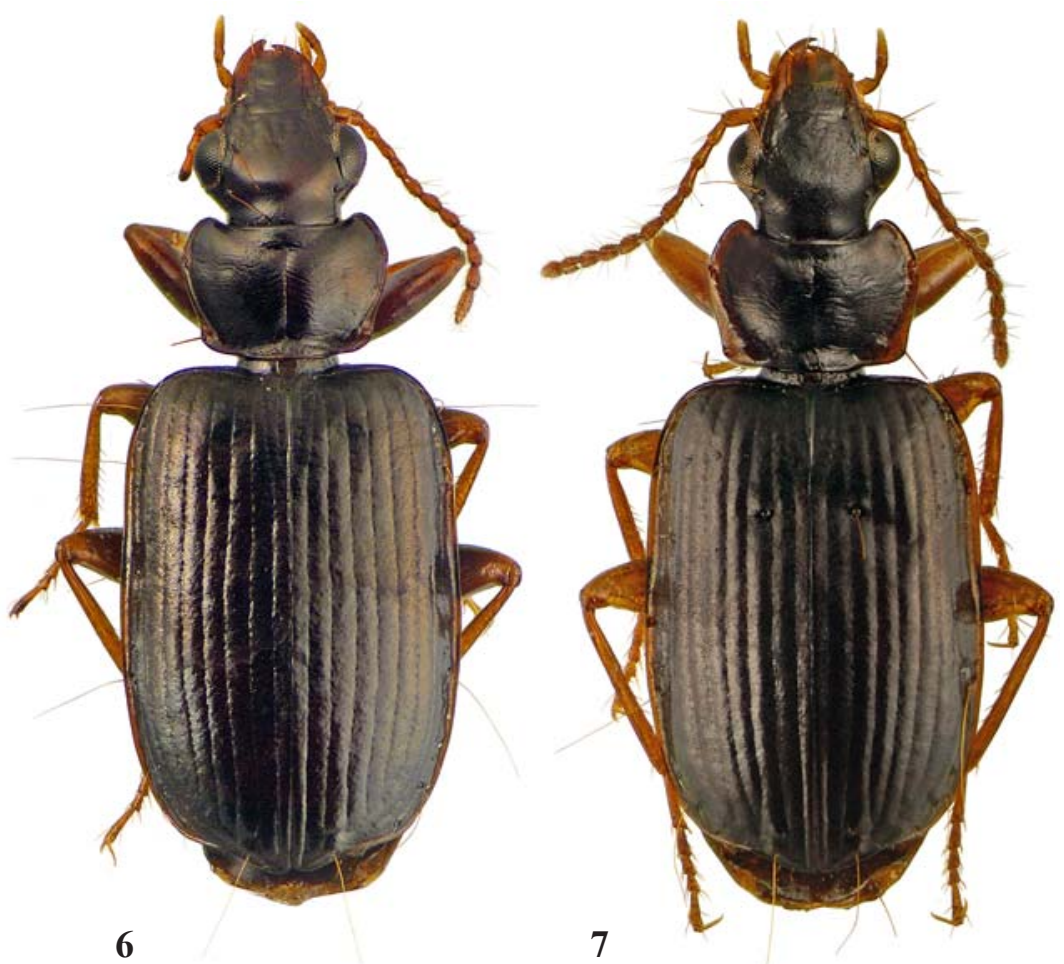

Figs 6-7. Dorsal habitus, holotypes: 6 - Tantillus subnitens sp.n.; $7-$ T. reflexicollis sp.n.

Рис. 6-7. Габитус сверху, голотипы: 6 - Tantillus subnitens sp.n.; 7 -T. reflexicollis sp.n. 
HABITATS AND HABITS. The adults live under exfoliated bark of standing or fallen dead trees. Incrassate femora with strong seta on hind femora and highly derived condition of the elytral umbilical setae seem to be morphological adaptations to this way of living.

COMMENTS. According to the descriptions, Tantillus and Mochtheroides are only different from each other in having discal seta $\mathrm{d} 1$ present or absent from the elytron, respectively. Andrewes [1923] explained that he introduced the name Mochtheroides for Masoreus sericans SchmidtGöbel, 1846 because he failed in placing this species in any other pericaline genus. He mentioned Tantillus but later [Andrewes, 1931], which suggests that the genus was unknown or little-known to him that time.

The closest ally of Tantillus is Miscelus Klug, 1834. The two genera share a number of derived characters, including such synapomorphies as the setose gula and the distinctive pattern of umbilical setae. Body shape is also similar, including more or less parallel-sided elytra and rather a convex pronotum, with lateral margin bead-like in most species. Miscelus and many species of Tantillus share incrassate femora and seta $\mathrm{d} 3$ only present close to elytral apices. Adult habits are very similar in both genera, too.

On the other hand, many derived characters appear to have been evolved within either genus in parallel. These characters are numerous in Miscelus, among them only one supra-ocular seta and two paragular setae on each side, smooth claws, antennomere 3 distinctly pubescent in apical half, glabrous metafemora, and the metacoxa with anterolateral seta only retained. Tantillus has at least two derived characters, sternite VII bisetose in both sexes (inner setae reduced) and distal anteroventral seta on the metafemur strengthened and shifted to preapical position.

\section{Key to SPECIES OF TANTILLUS}

1(12) Elytron with two discal setae, $\mathrm{d} 1$ before middle and $\mathrm{d} 3$ close to apex.

2(3) Elytra deeply sinuate close to apices; these rounded separately each and slightly extended apicad. Pronotum rounded on sides, with basal angles rounded and apical angles widely rounded; lateral margin widely explanate; microsculpture very transverse. - Philippines (Mindanao) ............ T. philippinensis (Jedlièka, 1934), comb.n.

3(2) Apical truncature of elytron moderately sinuate at middle; apices not produced, nearly contiguous, with blunt tips. Pronotum sinuate on sides posteriorly, basal angles well-defined, obtuse to nearly right, apical angles blunt or narrowly rounded; reflexed lateral margin very narrow in apical half.
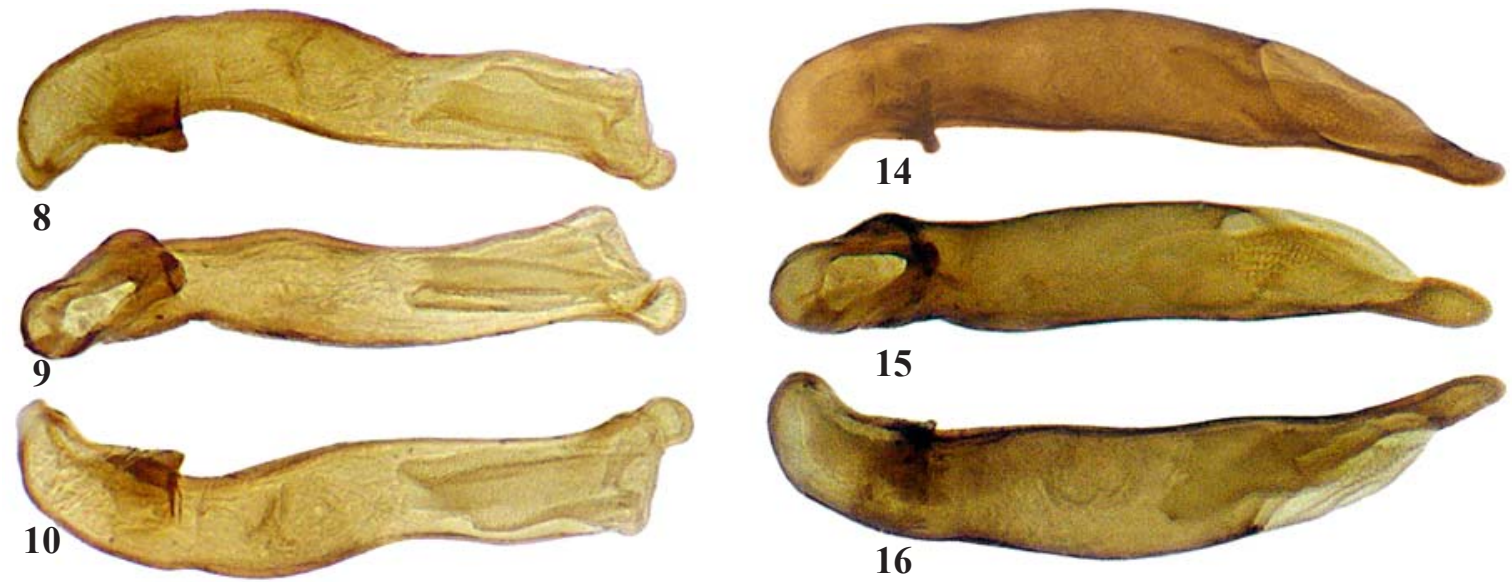

15
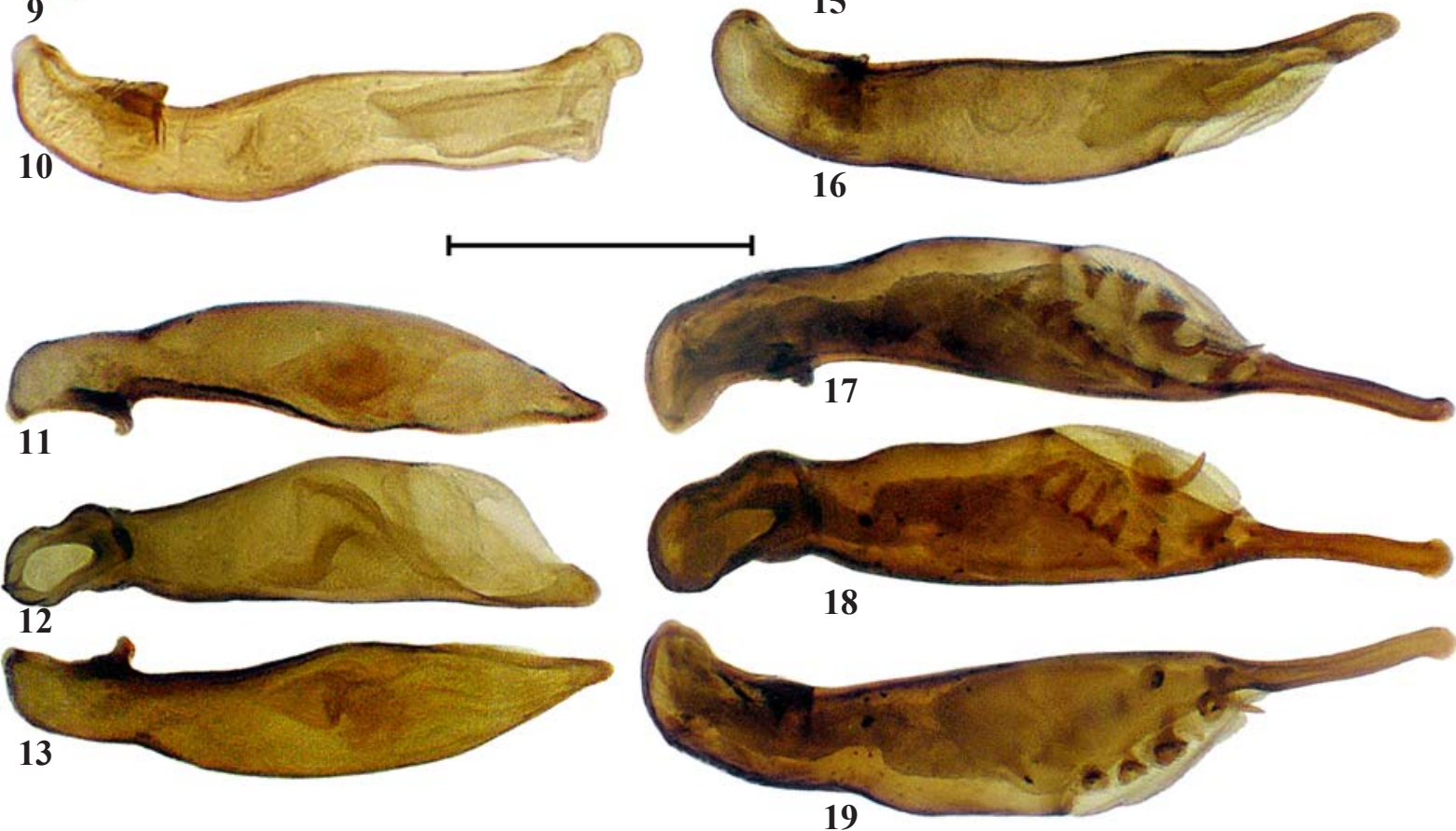

Figs 8-19. Median lobe of aedeagus: 8-10 - Tantillus brunneus; 11-13 - T. quadripunctatus sp.n.; 14-16 - T. semiopacus sp.n.; 17-19 - T. longipenis sp.n.; 8, 11, 14, 17 - left aspect; 9, 12, 15, 18 - ventral aspect; 10, 13, 16, 19 - right aspect. Scale bar: $0.5 \mathrm{~mm}$. Рис. 8-19. Средняя доля эдеагуса: 8-10 - Tantillus brunneus; 11-13 - T. quadripunctatus sp.n.; 14-16 - T. semiopacus sp.n.; 17-19 - T. longipenis sp.n.; 8, 11, 14, 17 - слева; 9, 12, 15, 18 - снизу; 10, 13, 16, 19 - справа. Масштаб: 0.5 мм. 
4(5) Body large, BL $9 \mathrm{~mm}$. Clypeus longer than wide, well rounded and deeply sinuate apically. Head conspicuously convex and tri-impressed between eyes, with deep neck constriction and genae as long as eyes. Meso- and metafemora slender, the latter bisetose. Base of pronotum truncate. Elytral striae deep, intervals 7 and 8 subcarinate inside in basal half. Pronotum shiny, elytra less so. In male, mesotibia with six tubercles along inner margin, pro- and mesofemora with short and dense ventral pubescence, abdomen smooth. - Sabah, Borneo ............................... T. imbricatus sp.n.

5(4) Body much smaller, BL under $5 \mathrm{~mm}$. Clypeus quadrate, as long as wide, without or with very gentle emargination at apex. Head flat and smooth between eyes, neck constriction imperceptible. Femora incrassate. Base of pronotum produced. Elytral striae rather shallow, intervals slightly convex. In male, mesotibia trituberculate along inner margin, pro- and mesofemora smooth, abdominal sternites III and sometimes also IV each with a median tuft of short and strong close setae.

6(7) Legs and antennae red, femora infuscated except at apices. Body unicolored black and dull from very coarse microsculpture. Labrum evenly rounded apically. Metafemur with 4-5 strong setae. BL $4.9 \mathrm{~mm}$. Abdominal sternites III and IV each with a median tuft of setae in male. - Sri Lanka ................ T. quadripunctatus sp.n.

7(6) Legs and antennae reddish-yellow, body brown to black, unicolored or with rather pale elytra. Metafemur bisetose. Only abdominal sternite III with a median tuft of setae in male.

8(9) Body black, reflexed lateral margins of both pronotum and elytra red. Pronotum inversely trapezoidal and more transverse, almost two thirds wider than long; its sides vaguely sinuate in basal half and rather widely explanate-reflexed behind. Labrum very gently sinuate apically. In male, abdominal sternite III with a deep median pit bearing tuft of setae. - Southern India ................ T. reflexicollis sp.n.

9(8) Head and pronotum brown rather dark, elytra brown or red. - Species from Sri Lanka.

10(11) Elytra brown. Male abdominal sternite III with a shallow median pit bearing sparse and slender setae. BL 4.2-4.5 mm .................... T. brunneus Chaudoir, 1869

11(10) Elytra red, with black suture. BL $5 \mathrm{~mm}$

T. vittatus Bates, 1886

12(1) Elytron with one discal seta (d3) close to apex.

13(14) Pronotum wider at apex than at base. BL $4.8 \mathrm{~mm}$. Philippines (Sibuyan Is.); New Britain [Darlington, 1968: 124] .................................... T. niger (Jedlička, 1934)

14(13) Pronotum slightly wider at base than at apex.

15(16) Dorsum shiny, without sericeous lustre. Sides of pronotum very gently sinuate in front of basal angles; these very obtuse, with apices nearly rounded off. Elytral striae moderately deep and minutely, almost imperceptibly punctate at bottom. Microsculpture rather superficial, more so on elytra. Antennae short, not quite reaching base. BL 4.6-4.8 mm. - Southern Vietnam ................ T. subnitens sp.n.

16(15) Dorsum more or less sericeous, at least basal half of elytra dull (both characteristics depend on spotlight direction).

17(18) Sides of pronotum nearly straight in front of obtuse basal angles. Elytral striae very finely punctate. BL $5 \mathrm{~mm}$. - Myanmar (Tenasserim), Singapore, Sumatra ............ .............. T. sericans (Schmidt-Göbel, 1846), comb.n.

18(17) Sides of pronotum distinctly sinuate just in front of obtuse basal angles; elytral striae smooth or very finely crenulate. Body slightly larger, BL $5.3-6.2 \mathrm{~mm}$.

19(20) Elytra slightly shorter, EL/EW 1.36; microsculpture very dull. Median lobe of aedeagus with apex very long, internal sac with small spines. - Southern Vietnam ....
20(19) Elytra slightly longer, EL/EW 1.42-1.48; microsculpture slightly more superficial. Median lobe of aedeagus with apex much shorter, internal sac without sclerites. Southern Vietnam T. semiopacus sp.n.

\section{Tantillus semiopacus Fedorenko, sp.n.}

Figs 1, 14-16, 34-35.

MATERIAL. Holotype $\sigma^{7}$ (ZMMU) labelled: 'S[outh] Vietnam, Lam Dong Prov[ince]., Bi Doup-Nui Ba Nat[ure]. Res[erve]., env. Long Lanh, $12^{\circ} 10^{\prime} 44^{\prime \prime} \mathrm{N} / 108^{\circ} 40^{\prime} 44^{\prime \prime} \mathrm{E}, \mathrm{h}=1400-1600 \mathrm{~m}$, 30.IV.2009, leg. D. Fedorenko'. Paratypes (ZISP, SIEE): $50^{7} \sigma^{7}$, 4 웅 same data, but 11-30.III.2008; $O^{\top 7}$ (SIEE), same locality, except for but $12^{\circ} 11^{\prime} \mathrm{N} / 108^{\circ} 42^{\prime} \mathrm{E}, \sim 4 \mathrm{~km} \mathrm{SSE}$ of Hon Giao Mt., $\mathrm{h}=1500-$ 1800 m, 5.V.2009; $\bigcirc^{7}, 2$ 우, Dak Lak province, Chu Yang Sin Natn. Park, $12^{\circ} 25^{\prime} 11^{\prime \prime} \mathrm{N} / 108^{\circ} 21^{\prime} 55^{\prime \prime}$ E, Krong Kmar river, upper flow, $\mathrm{h}=1100 \mathrm{~m}, 15-30 . \mathrm{V} .2014$, D. Fedorenko leg.

DESCRIPTION. BL 5.3-6.2 mm. Body (Fig. 1) dark brown to black, antennae, mouthparts, legs and labrum entirely or apically and along sides red; femora slightly to clearly infuscated, except at extreme bases and apices, reddish brown to brown rather dark. Abdomen along middle and very narrow reflexed lateral margins of elytra reddish. Microsculpture isodiametric and moderately coarse on head, transverse and coarse on pronotal disc. Elytra with microsculpture somewhat squamose, barely transverse, nearly isodiametric, and very gently oblique lateroapicad, more oblique and asperate laterally. Meshes of pronotal and elytral microsculpture not fully in horizontal plane so that shine of dorsum depends on spotlight direction. As a result, apical half of pronotum and elytra, excluding bases, rather shiny, otherwise dull, with some sericeous luster, in frontal light; in caudal light, elytra very dull and pronotum in apical half less so while basal half of pronotum and elytra before apex rather shiny.

Head a little convex, smooth, minutely and very sparsely punctate anteriorly, with vague $\mathrm{V}$-shaped impression just behind clypeus. Neck constriction indistinct. Eyes moderately large and moderately convex, extended into genae in a straight line; genae about half as long as eye and meeting neck at very obtuse angle. Labrum as long as wide, apical margin gently to indistinctly emarginate in the middle. Antennae surpassing base of pronotum by apical two antennomeres. Gular setae two.

Pronotum transversely cordate, broadest a third from apex, evenly rounded on sides, less so behind anterolateral seta, sinuate just in front of obtuse basal angles, PW/PL 1.38-1.50 (1.44, n=5), PW/HW 1.20-1.26 (1.22). Base evenly convex caudad, $\mathrm{PWb} / \mathrm{PWa} 1.08-1.12$ (1.10), with a faint concavity between median part and side; apex evenly sinuate, with almost indistinct median angle; apical angles produced forward, with blunt tips. Disc very convex and smooth, reflexed lateral margin very narrow and bead-like, slightly wider at basal angles. Median line fine and deep, entire or slightly shortened basally and apically. Either transverse impressions, basal and apical, subequally deep or the latter less so. Basal bead entire to very fine or obliterate medially; apical bead obliterate at middle.

Elytra as for the genus, EL/EW 1.42-1.48 (1.45), EW/PW 1.58-1.68 (1.61). Apical truncature gently sinuate, apices contiguous and mostly blunted combined. Striae shallow, vaguely crenulate; intervals subconvex. One discal seta present, d3.

Abdomen glabrous in male.

Femora incrassate, slightly sulcate ventrally in apical $3 / 5$ or $1 / 5$, or $2 / 5$ in fore, middle and hind legs, respectively. Metafemur bisetose. Pro- and mesofemora with short and moderately dense pubescence in male. Mesotibia with five preapical tubercles along inner margin in male.

Aedeagus (Figs 14-16, 34-35): apical orifice well defined, apical lamella long and slightly upturned at tip, parallel-sided and narrowly rounded at tip in ventral view; internal sac unarmed.

DIAGNOSIS. See key to species. 
DISTRIBUTION. Known from two close localities in the Dalat Plateau, southern Vietnam.

HABITATS AND HABITS. All adults have been collected under bark of standing or fallen dead trees at the edges of monsoon forests.

NAME. Refers to rather a dull body dorsum.
Tantillus longipenis Fedorenko, sp.n.

Figs 2, 17-19, 36-37.

MATERIAL. Holotype $\mathrm{O}^{7}$ (ZMMU) labelled: 'S[outh] Vietnam, Dongnai Province, Nam Cat Tien National Park, $11^{\circ} 25^{\prime} \mathrm{N}$ $107^{\circ} 25^{\prime}$ E, 14-31.IV.2009, A. Polilov leg.', 'Lagerstroemia calyculata forest, window trap on Sterculia tree, $\mathrm{h}=25-30 \mathrm{~m}$ above ground'.
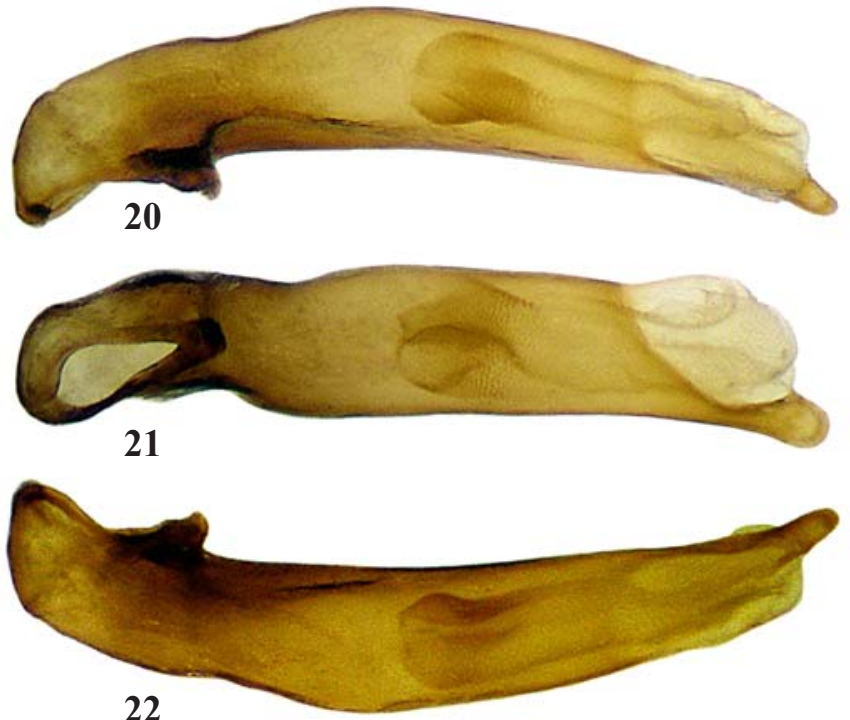
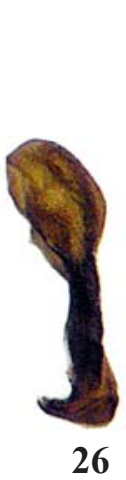

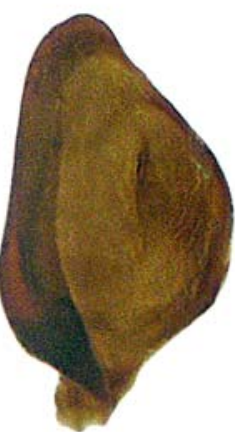

27
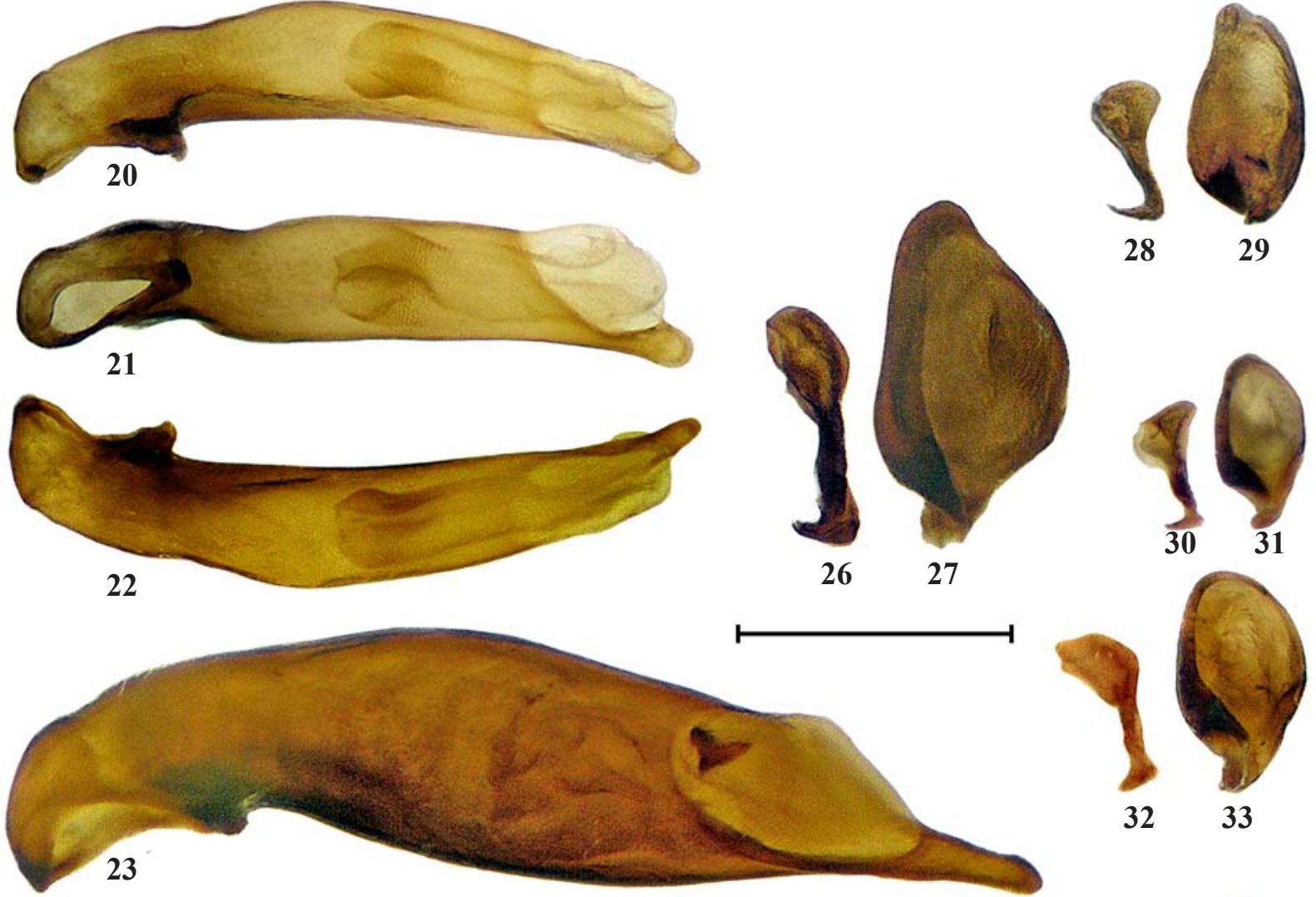

32

33
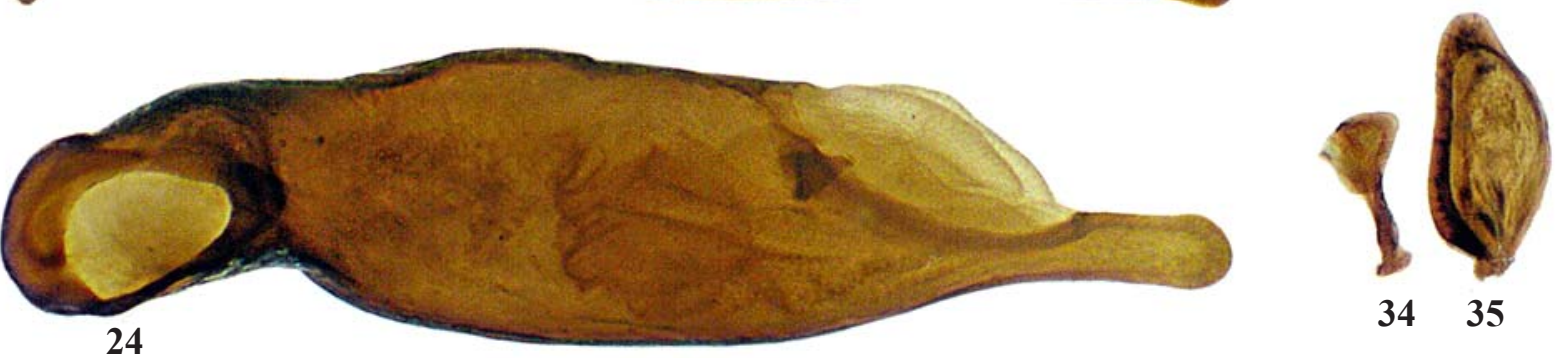

$34 \quad 35$
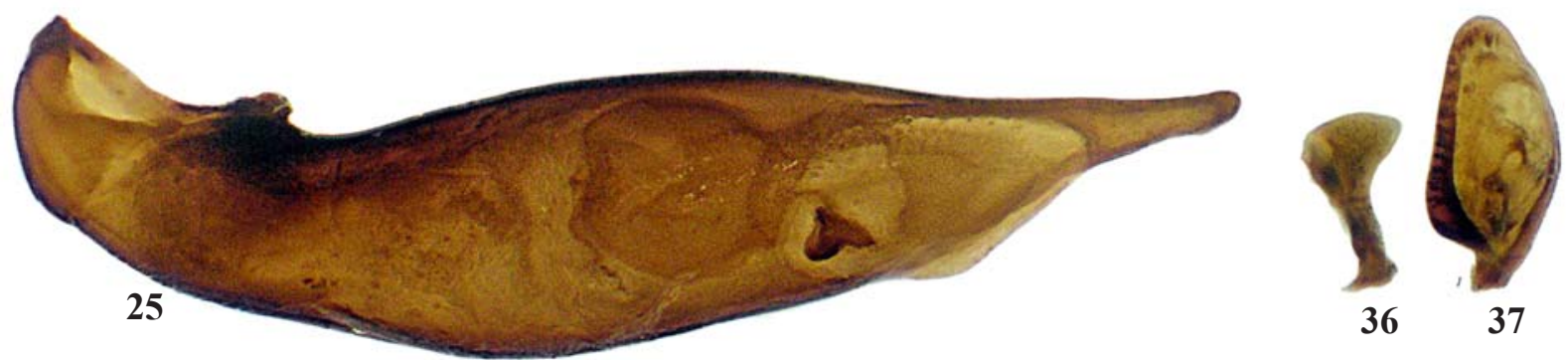

Figs 20-37. Aedeagus: 20-22, 32-33 - Tantillus reflexicollis sp.n.; 23-27 - T. imbricatus sp.n.; 28-29 - T. brunneus; 30-31 T. quadripunctatus sp.n.; 34-35 - T. semiopacus sp.n.; 36-37 - T. longipenis sp.n.; 20-25 - median lobe; 26, 28, 30, 32, 34, 36 - right paramere; 27, 29, 31, 33, 35, 37 - left paramere; 20, 23 - left aspect; 21, 24 - ventral aspect; 22, 25 - right aspect. Scale bar: $0.5 \mathrm{~mm}$.

Рис. 20-37. Эдеагус: 20-22, 32-33 - Tantillus reflexicollis sp.n.; 23-27-T. imbricatus sp.n.; 28-29-T. brunneus; 30-31-T. quadripunctatus sp.n.; 34-35 - T. semiopacus sp.n.; 36-37 — T. longipenis sp.n.; 20-25 — средняя доля; 26, 28, 30, 32, 34, 36 — правая парамера; 27, 29, 31, 33, 35, 37 - левая парамера; 20, 23 - слева; 21, 24 - снизу; 22, 25 - справа. Масштаб: 0.5 мм. 
DESCRIPTION. As to the previous species (Fig. 2), except for the following points. BL $5.6 \mathrm{~mm}$. Dorsum dull from a coarser microsculpture. Pronotum with basal bead very fine medially, PW/PL 1.54, PW/HW 1.21. Elytra slightly shorter, EL/EW 1.36, EW/PW 1.59.

Aedeagus (Figs 17-19, 36-37) distinctive due to apex being extremely long; internal sac with numerous large spines.

DIAGNOSIS. Distinctive male genitalia only differentiate this species from T. semiopacus sp.n.

DISTRIBUTION. Only known from the type locality, Cat Tien National Park, Dong Nai Province, southern Vietnam.

HABITATS AND HABITS. See the second label of the holotype.

NAME. Refers to very long apex of the aedeagus median lobe.

\section{Tantillus subnitens Fedorenko, sp.n.}

Fig. 6.

MATERIAL. Holotype + (ZMMU) labelled: 'S[outh] Vietnam, Lam Dong Prov[ince]., Bi Doup-Nui Ba Nat[ure]. Res[erve]., env. Long Lanh, $12^{\circ} 10^{\prime} 44^{\prime \prime} \mathrm{N} / 108^{\circ} 40^{\prime} 44^{\prime \prime} \mathrm{E} / \mathrm{h}=1400-1600 \mathrm{~m}$, 29.IV.2009, leg. D. Fedorenko'. Paratype + (SIEE): same data, but 29-30.III.2008

DESCRIPTION. BL 4.6-4.8 mm. Body (Fig. 6) shiny black, not sericeous, with slightly reddish reflexed lateral margins of both pronotum and elytra; antennae, mouthparts, tibiae and tarsi red, femora infuscated but apices (femoral bases, coxae, trochanters and abdomen reddish in the paratype). Microsculpture moderately coarse, isodiametric on head and elytra, moderately transverse on pronotal disc.

Otherwise similar to T. semiopacus sp.n. except as follows: Frons and vertex barely more convex and neck constriction a bit more distinct. Antennae short, not quite reaching elytral base. Gular setae missing.

Pronotum transverse, inversely trapezoidal, broadest a third from apex, PW/PL 1.49-1.52, PW/HW 1.19-1.21. Basal margin slightly less convex, apical margin a little less concave, nearly straight medially, $\mathrm{PWb} / \mathrm{PWa} 1.15-1.16$. Sides gently sinuate just in front basal angles; these very obtuse and rounded apically due chiefly to sides of base very oblique and rounded just behind. Disc less convex.

Elytra: EL/EW 1.49-1.55, EW/PW 1.56-1.61. Apical truncature gently sinuate, apices almost contiguous or blunted separately each. Striae shallow, crenulate and minutely to indistinctly punctate; intervals nearly flat.

DIAGNOSIS. Distinctive in the combination of the body small-sized, shiny, without sericeous luster, and minutely punctate elytral striae.

DISTRIBUTION. Known from the type locality only.

HABITATS AND HABITS. Same as in T. semiopacus

sp.n., with which it lives syntopically.

NAME. Refers to rather a shiny body dorsum.

\section{Tantillus quadripunctatus Fedorenko, sp.n.} Figs 3, 11-13, 34-35.

MATERIAL. Holotype $\sigma^{7}$ (ZISP), with a handwritten label 'Šri Lanka. Vilpattu, Talawila. 8.X.982 Medvedev'.

DESCRIPTION. Same as T. semiopacus sp.n. except as follows: BL $4.9 \mathrm{~mm}$. Body (Fig. 3) very dull black, otherwise same colored, but only abdominal sternites III-IV red medially. Microsculpture coarse, isodiametric to somewhat granulate on head, moderately transverse on pronotum, barely transverse on elytra.

Head larger and barely more convex. Labrum convex at apical margin. Gular setae two.

Pronotum: PW/PL 1.34, PW/HW 1.10, PWb/PWa 1.05. Apex and base both straight medially, sides of base slightly in advance of the median part. Basal bead fine and entire; apical bead extremely fine, obliterate at middle. Disc slightly rugulose. Elytra: EL/EW 1.47, EW/PW 1.50. Apices almost contiguous. Striae shallow, vaguely crenulate. D1/EL 0.30 .

Abdominal sternites III and IV each with a median tuft of fairly short and strong setae (in male).

Metafemur with four long setae. Pro- and mesofemora glabrous in male. Mesotibia with three preapical tubercles along inner margin in male.

Aedeagus (Figs 11-13, 34-35): apical orifice well defined, apical lamella moderately long, in ventral view subtriangular, with rounded tip; internal sac unarmed.

DIAGNOSIS. See key to species.

DISTRIBUTION. Known from the type locality only.

HABITATS AND HABITS. No data.

NAME. Refers to the number of elytral discal setigerous pores.

\section{Tantillus reflexicollis Fedorenko, sp.n.}

Figs 7, 20-22, 32-33.

MATERIAL. Holotype $\sigma^{7}$ (ZMMU) labelled: 'S[outh]-India, Western Ghats, Tamil Nadu, $35 \mathrm{~km}$ SW of Kodaikanal, Kukai Shola, $10^{\circ} 16^{\prime} 23^{\prime \prime} \mathrm{N} / 7^{\circ} 21^{\prime} 55^{\prime \prime} \mathrm{E}, \mathrm{h}=2060 \mathrm{~m}$, leg. S. Saluk, 30.XI.2003'.

DESCRIPTION. BL 4.8 mm. Body (Fig. 7) black; antennae, mouthparts, legs and reflexed lateral margins of both pronotum and elytra red; labrum slightly reddish. Head dull, neck shiny, elytra and especially pronotum slightly less so. Microsculpture granulate on head, becoming isodiametric on neck and adjacent parts of vertex, moderately coarse and moderately transverse on pronotal disc, with a group of isodiametric meshes just medially; elytral microsculpture isodiametric, moderately coarse and slightly squamose.

Otherwise similar to T. subnitens sp.n. except as follows: antennae surpassing base of pronotum by apical two antennomeres.

Pronotum broadest a fourth from apex, disc convex, apical angles more produced, sides indistinctly sinuate in basal half. Reflexed lateral margin increasingly wide behind anterolateral seta until wide at basal angle. PW/PL 1.64, PW/ HW 1.22, PWb/PWa 1.28. Base nearly straight, with slightly produced middle part and sides rounded close to almost rounded basal angles. Disc transversely and very shallowly rugulose. Apical transverse impression shallow. Basal and apical beads obliterate medially.

Elytra: D1/EL 0.27, EL/EW 1.44, EW/PW 1.61. Striae almost indistinctly punctulate.

Abdominal sternite III with dense and very short setae in a small and deep median pit.

Metafemur bisetose. Pro- and mesofemora glabrous in male. Mesotibia with four preapical tubercles along inner margin in male.

Aedeagus (Figs 20-22, 32-33): apical orifice well defined, apex moderately long, nearly parallel-sided and widely rounded at tip in ventral view; internal sac unarmed.

DIAGNOSIS. This species is most similar to T. subnitens sp.n. and distinguishable from it by having pronotal lateral margin rather widely reflexed and the elytra with discal setae d1.

DISTRIBUTION. Known from the type locality only.

HABITATS AND HABITS. No exact data.

NAME. Refers to conspicuously reflexed lateral margin of the pronotum.

\section{Tantillus brunneus Chaudoir, 1869}

Figs 4, 8-10, 28-29.

Chaudoir, 1869: 126 (Ceylon).

MATERIAL. Two syntypes, $\sigma^{7} \bigcirc$ (MNHN), labelled: 'Ex Musaeo Chaudoir'. The male specimen is designated as lectotype. 
REDESCRIPTION. BL 4.2-4.5 mm. Body (Fig. 4) brown rather dark, elytra slightly paler; mouthparts, legs and antennae reddish-brown. Dorsum, especially head and elytra, dull from coarse microsculpture, isodiametric on head, nearly granulate and squamose on elytra. Pronotal microsculpture rather strongly transverse and superficial on each side of midline, becoming isodiametric towards apical angles.

Eyes slightly flattened, twice as long as genae, these almost longitudinal and smoothly extended into neck. Labrum nearly quadrate, slightly contractedapicad and sinuate apically. Antennae almost reaching elytral base. Gula bisetose.

Pronotum very convex, cordate, broadest and slightly angulate a third from apex on a level with anterolateral seta, PW/ PL 1.38-1.43 (1.41, n=3), PW/HW 1.17-1.27 (1.22), PWb/ PWa 1.16-1.20 (1.18). Sides straight before and behind this seta, rounded apically, gently sinuate in front of basal angles. Base slightly produced and twice as wide as its sides, these oblique and rounded just behind very obtuse basal angles. Apex straight medially, apical angles produced, with blunt tips. Basal bead entire, apical bead obliterate medially, both fine. Median line fine and moderately deep, obliterate in front of apical transverse impression and behind basal one, which is fairly deep and deeper laterally. Reflexed lateral margin as a fine bead in apical half, slightly wider behind.

Elytra: EL/EW 1.42-1.46 (1.44), EW/PW 1.55-1.62 (1.59). Apical truncature distinctly sinuate. Striae moderately deep, nearly smooth, intervals gently convex. D1/EL $0.25-0.28(0.26, \mathrm{n}=2 \times 2)$

Abdominal sternite III with fairly sparse hairy tuft in a very small median pit in male.

Femora incrassate. Metafemur with preapical seta and probably also with subbasal seta. In male, mesofemur glabrous and mesotibia with three small tubercles at inner margin.

Aedeagus (Figs 8-10, 28-29): apical orifice nearly indistinct, apex very short, broadening apicad and widely rounded; internal sac unarmed.

Paralectotype. Smaller, with pronotum evenly rounded laterally because of no lateral angle; basal angles slightly obtuse due to sides less sinuate in front of them and sides of base poorly rounded. Elytral apical truncature subsinuate and intervals nearly flat.

DIAGNOSIS. The species of brown body colour, with elytral seta $\mathrm{d} 1$, and distinctive aedeagus.

DISTRIBUTION. Sri Lanka.

HABITATS AND HABITS. No data.

Tantillus imbricatus Fedorenko, sp.n. Figs 5, 23-27.

MATERIAL. Holotype $\sigma^{7}$ (ZMMU) labelled: 'E[astern] Malaysia, Sabah, Mt. Kinabalu N.P., 1700 m, 16-30. 07. [20]02, Kurbatov \& Zimina'.

DESCRIPTION. BL 9 mm. Body (Fig. 5) black, antennae, mouthparts, femoral apices, tibiae and tarsi red; labrum and very narrowly reflexed lateral margins of elytra reddish-brown. Head and pronotum moderately shiny, elytra dull. Microsculpture isodiametric on head, coarse on forehead, more superficial behind; pronotum with very transverse superficial microsculpture. Elytral microsculpture isodiametric, imbricate and rasp-like.

Head very convex and shallowly tri-impressed across vertex, very finely and densely striated between eyes, with a vague Yshaped impression just behind clypeus. Neck constriction deep and wide. Eyes moderately large and moderately convex, extended into genae in a straight line; gena as long as eye and meeting neck at very obtuse angle. Labrum slightly longer than wide, conspicuously emarginate at middle of apical margin, longitudinally concave on each side of median line. Antennae surpassing pronotal base by apical three segments. Gula bisetose.
Pronotum transversely cordate, broadest two fifths from apex, PW/PL 1.54, PW/HW 1.24, PWb/PWa 1.22. Base nearly straight, with median part very slightly produced; apex sinuate, almost straight medially; apical angles porrect, slightly blunted. Sides evenly rounded, sinuate in front of obtuse basal angles. Disc convex and smooth, with faint crossstriations and a fairly wide yet very shallow sublateral groove running from base to apex and bearing dense transverse wrinkles. Reflexed lateral margin narrow in apical third, moderately wide behind, more so at basal angles. Median line fine and deep, not quite reaching apex, obliterate basally. Basal transverse impression deep and angulate forward, apical transverse impression obsolete. Basal bead fine and entire, apical bead very fine, obliterate medially.

Elytra fairly long, EL/EW 1.56, EW/PW 1.57. Apical truncature gently sinuate, apices almost contiguous. Striae deep, vaguely crenulate; intervals subconvex on disc, convex before apex. Intervals 6 and 7 subcarinate internally in basal half or fourth, respectively. D1/EL 0.35

Abdominal sternites III and IV densely setulose at middle (in male only?).

Profemora incrassate, meso- and metafemora slender, without distinct ventral sulci. Metafemur bisetose. In male, proand mesofemora with short and moderately dense pubescence; mesotibia with six preapical tubercles along inner margin.

Aedeagus (Figs 23-27): apical orifice well defined, apical lamella long, with a small terminal capitulum, parallelsided, slightly broadened and widely rounded at tip in ventral view; internal sac with a medium sized spine.

DIAGNOSIS. The largest species of the genus with the head convex and tri-impressed, the labrum long and distinctly sinuate, and the elytra long, with imbricate microsculpture.

DISTRIBUTION. Sabah, Borneo.

HABITATS AND HABITS. No data.

NAME. Refers to the imbricate elytral microsculpture.

ACKNOWLEDGEMENTS. I am very indebted to Dr. Th. Deuve and A. Taghavian (both MNHN) and Dr. B.M. Kataev (ZISP) for the loan of the material under their care, as well as to I.V. Melnik (Moscow) and Dr. S.V. Saluk (Minsk) for donating specimens.

\section{References}

Andrewes H.E. 1923. On the types of Carabidae described by Schmidt-Goebel in his Faunula Coleopterorum Birmaniae // Trans. Ent. Soc. London. P.1-63.

Andrewes, H.E. 1931. Papers on Oriental Carabidae.-XXV // Ann. \& Mag. Nat. Hist. Ser.10. Vol.7. P.513-528.

Andrewes H.E. 1933. A Catalogue of the Carabidae of Sumatra // Tidschr. Entomol. Jg.76. S.19-382.

Bates H.W. 1886. On the Geodephagous Coleoptera collected by $\mathrm{Mr}$. George Lewis in Ceylon// Ann. \& Mag. Nat. Hist. Ser.5. Vol.17. P.199-212.

Chaudoir M. 1869. Mémoire sur les Thyréoptérides // Ann. Soc. Ent. Belg. T.12. P.113-162.

Csiki E. 1932. Carabidae. Harpalinae VII // Junk W., Schenkling S. (Hrsg.). Coleopterorum Catalogus. Vol.3. Pt.124. Berlin: W.Junk. S.1279-1598.

Darlington P.J. 1968. The Carabid beetles of New Guinea Part III. Harpalinae (continued): Perigonini to Pseudomorphini // Bull. Mus. Harvard. Vol.137. No.1. P.1-253.

Jedlička A. 1934. Neue Carabiden Aus Ostasien (VI. Theil) // Acta Ent. Mus. Nat. Pragae. Vol.12. P.122.

Jedlička A. 1963. Monographie der Truncatipennen aus Ostasien. Lebiinae - Odacanthinae - Brachininae (Coleoptera, Carabidae) // Ent. Abh. Staatl. Mus. Dresden. Bd.28. Hf.7. S.269-579.

Schmidt-Göbel H.M. 1846. Faunula Coleopterorum Birmaniae, adjectis nonnulis Bengaliae indigenis. viii +94 pp. + iii tab. 